\title{
Evaluation of home care services at a training and research hospital in Izmir
}

\author{
İzmir'de bir eğitim ve araștırma hastanesinde evde bakım hizmetlerinin değerlendirilmesi
}

Muhteber COLAK, Ozden GOKDEMIR, Seval YAPRAK, Mehtap KARTAL

\begin{abstract}
Objectives: To define the demographic characteristics, health and dependence status of patients receiving home care services (HCSs) and the services needed and received by the patients.

Patients and Methods: It is a descriptive study including 120 patients that had HCSs from a training and research hospital home care unit, where the files of the patients were evaluated retrospectively between January and August 2010.

Results: Most of the patients in need of HCSs were female $(61.8 \%)$, their mean age was $72.6 \pm 16.4$ (range: 16-105) and $75.5 \%$ were 65 years and above, while $79.2 \%$ were bedridden. The personal hygiene and nutritional status were deemed inappropriate in $21.7 \%$ and $31.7 \%$, respectively. The most common diseases were hypertension (19.3\%), cerebrovascular accidents (13.5\%), and Alzheimer's disease (9.5\%). Family members mentioned their training needs' topics as nutrition (30.3\%), sanitation-hygiene $(21.2 \%)$, and general care $(18.2 \%)$.

Conclusion: The study has shown different aspects of HCSs including medical, nursing, and social welfare problems for all parties, especially family physicians. People applied for HCSs were mostly women, elders with impaired functional status and bedridden. Their caregivers were mostly family members who needed social support not only in economic means but also in training so that they can provide better care for their relatives.
\end{abstract}

Keywords: Home health-care services, Dependence status, Caregiver
ÖZ

Amaç: Evde sağlık hizmeti (ESH) alan hastaların, demografik özelliklerini, sağlık ve bağımlılık durumları ile aldıkları ve ihtiyaç duydukları hizmetleri tanımlamaktır.

Hastalar ve Yöntem: İzmir'de bir eğitim araştırma hastanesi evde bakım biriminden Ocak-Ağustos 2010 arasında ESH alan 120 hastanın dosyaları geriye dönük olarak incelenmiştir.

Bulgular: ESH ihtiyacı olanların çoğu kadın $(\% 61,8)$,

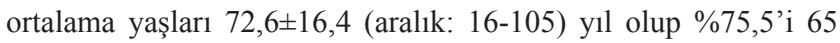
yaş ve üzerindeyken \%79,2'si yatağa bağımlıdır. Sırasıyla \%21,7 ve $\% 31,7$ 'sinin kişisel hijyen ve beslenme durumları yetersiz olarak değerlendirilmiştir. En sık görülen hastalıklar hipertansiyon $(\% 19,3)$, serebrovasküler hastalıklar $(\% 13,5)$ ve Alzheimer hastalığ $(\% 9,5)$ 'dır. Aile bireyleri, beslenme (\%30,3), sanitasyonhijyen $(\% 21,2)$ ve genel bakım $(\% 18,2)$ konularında eğitim almak ihtiyacı duyduklarını belirtmişlerdir.

Sonuç: Bu çalışma, tüm taraflar için, özellikle aile hekimleri için, tıbbi ve hemşirelik alanları ile sosyal yardım kapsamındaki alanlarda ESH'nin farklı yönlerini göstermektedir. ESH için başvuranların çoğu kadın, yaşlı, fonksiyonel durumu bozuk ve yatağa bağımlıdırlar. Bakım verenler, sadece ekonomik anlamda değil, hastalarına daha iyi hizmet verebilmek için eğitim anlamında da hizmet almak ihtiyacindadırlar.

Anahtar kelimeler: Evde sağlık hizmeti, Bağımlılık durumu, Bakımveren

\section{Introduction}

The modern description of hospice includes not only palliative care for the incurably ill given in hospitals or nursing homes, but also services provided to those who spend their last months or days of their lives at their own homes. In 1950s Dame Cicely Saunders pointed out the importance of palliative care in modern medicine in England [1, 2]. 
In the United States (US) most hospices started as home care-based programs. The basis of hospice initially began as a volunteer response that brought attention to the needs of the dying people, aiming patient-centered care provision and avoiding them from unnecessary medical interventions [2]. It is largely defined by the practices of the Medicare system and other health insurance providers, which make hospice care available, either in an inpatient facility or at the patient's home, to patients with a terminal prognosis who are medically certified to have life span less than six months. The US have shown a dramatic increase in the number of hospice programs, and number of persons served in the past two decades [3]. As of 2010, there were 5150 hospice provider programs and they served nearly 1,58 million Americans. Medicare decedents using hospices for their care need also showed an increase from $23 \%$ in 2000 to over $40 \%$ in 2009 , and approximately $41.9 \%$ of all deaths in the US in 2010 occurred within a hospice program care [1].

In countries other than the US, hospice tends to be primarily associated with the particular buildings or institutions that specialize in such care (although so-called "hospice at home" services may also be available) [4]. Home care is known as home-hospital, hospital without walls etc. and means medical care which is realized at home [5]. "Home Care" concept is fulfilled by different ways by different cultures. In Israel it is called as "hospital at home", in the US "home care", "home health care", "home nursing" while "home health care" or "home visiting" is used in East of Europe. In France, "home care-fin de vie" is used to describe [4].

Hospice services are designed to provide comprehensive interdisciplinary team-based palliative care for patients with limited life-time if the disease follows its known natural course [2]. It is the palliative care option that provides benefits for the dying person by not only limiting exposures of health risks of staying in a hospital but also having the opportunity of decrease the total health care costs [4]. The specialty of palliative medicine arose throughout the hospice movement. It incorporates the holistic care developed by hospice, focusing on symptom management, support and assistance via communication, and providing this care to a wider group of people including not only those are not dying but also those cannot receive hospice services [2]. Training have to be effectively identified including even oral hygiene commonly a problem for elderly, referrals have to be managed when needed between professional groups, and prevention for isolation of people with intellectual and physical disability to let them live their life time in dignity in their own environment $[7,8]$.

In Turkey, in 1993 the first project related to home care was planned by Social Services and Child Protection Agency as a pilot scheme in Ankara, Adana, Izmir and Istanbul but as this project could not attain effective results it did not continue [9]. In 1994, Metropolitan Municipality of Ankara established Elderly Services Centre (this become as Elderly Services and Compassion Houses) while Metropolitan Municipality of Istanbul established the Istanbul Health Enterprises Corporation. Also some companies, as forprofit, gave elderly care service at that time [10]. "Home care" is a new service sector in Turkey. Legal regulations were made on March $10^{\text {th }}, 2005$ named as "Regulation on Home Health Care Services" [11-13].

In the US or other developed countries hospice or home-care needs forced different profit or non-profit institutions to try to meet the needs of the people starting from elderly. As well Turkey's population is growing older, and the estimations of Turkish Statistical Institute (TUIK) elderly population being $7.5 \%$ of the population in 2013 will increase to $10.2 \%$ by 2023 [14]. However, hospice or home-care services were insufficient in numbers and had no integration with the health system to provide "home care services" (HCSs) properly, and they had to be paid by people as not covered by the insurance system. These needs led patients and/or elderly trying to have the care they needed in hospitals or rehabilitation centers whenever possible. But most of the time caregivers tried to do their best for their relatives in need of HCSs besides their insufficient knowledge about care giving that ended up in a decrease in individuals' life expectancy [15].

First legal arrangement about HCSs in Turkey, defined it as rehabilitation programs, physiotherapy, psychological treatment and medical needs (health and care) provided onsite where they live with their families [13]. HCSs developed through the new regulations which were made in 2010 . HCSs units which are connected to the hospitals and to the government public health centers are planned to be guided by primary care physicians (PCPs). However, people can directly apply for HCSs if they think that they need them, and calling a telephone number is enough to be accepted as a patient of HCSs [16].

PCPs have the responsibility for old, sick, bedridden, handicapped people giving the health care including 
prevention, diagnosis and treatment but also coordination of rehabilitation and consultancy services. They are the manager and coordinators of their patients' HCSs needs, which must be provided continuously, extensively with appropriate follow up in collaboration with other disciplines. However, for planning there is a necessity for defining of the target population and their needs within the scope of HCSs.

The aim of the study was to define not only the demographic characteristics, health and dependence status of patients receiving HCSs but also the services needed and received by them.

\section{Patients and Methods}

In this study, the patients' files who applied for HCSs between January and August 2010 to a Training and Research Hospital Home-Care Unit were evaluated retrospectively. The study was approved by the Medical Faculty Ethics Committee, and permission for the study was obtained from the Administration of the Training and Research Hospital.

The information within the files which had been filled by the same general practitioner consists of sociodemographic characteristics of the patients, the living conditions of the individual's house (ownership, heating, security, etc.), the one who is responsible for the patient's care, the needs of the patient (including walker, wheelchair, air bearing pad, percutaneous endoscopic gastrostomy (PEG), etc.), personal hygiene, presence of decubitus ulcers and pain, known diagnosis of the patients including chronic illness, the reasons for applying for HCSs and the HCSs given.

The data were presented with mean, standard deviation, numbers, and percentage values. The program used for statistical data analysis was SPSS 15.0.

\section{Results}

In this study 120 patient files were evaluated. Of the patients taking HCSs $61.8 \%$ were female, their mean age was $72.6 \pm 16.4$ (range: $16-105$ ) and $24.5 \%$ were below 65 . Of the patients $79.2 \%$ had health insurance, $16.7 \%$ had no income. The percentage of bedridden patients were $79.2 \%$, while $17.5 \%$ were nursed by formal caregivers. The sanitary conditions in $21.7 \%$ and nutrition in $31.7 \%$ were deemed inappropriate.

The reasons for HCSs applications were diaper report $(19.0 \%)$, medical board report for handicapped (14.8\%) and medication report (14.1\%), respectively (Table I).
Table I. Reasons for applying for HCSs

\begin{tabular}{|c|c|c|}
\hline & $\mathbf{n}$ & $\%$ \\
\hline Diaper report & 27 & 19.0 \\
\hline Medical board report for handicapped & 21 & 14.8 \\
\hline Medication report & 20 & 14.1 \\
\hline Others* & 17 & 12.0 \\
\hline Physiotherapist care & 12 & 8.5 \\
\hline Care for decubitus ulcer & 11 & 7.7 \\
\hline Report for formula feeding & 10 & 7.0 \\
\hline INR monitoring & 8 & 5.6 \\
\hline PEG exchange & 4 & 2.8 \\
\hline Report for wheelchair & 4 & 2.8 \\
\hline Foley catheter exchange & 3 & 2.1 \\
\hline Nutrition assessment & 3 & 2.1 \\
\hline Nasogastric catheter exchange & 1 & 0.7 \\
\hline Tracheostomy care & 1 & 0.7 \\
\hline Total & 142 & 100.0 \\
\hline
\end{tabular}

The diseases of patients ranged from hypothyroidism to Huntington's chorea, from filariasis to amyotrophic lateral sclerosis (ALS). The most common diseases were hypertension (19.3\%), cerebrovascular diseases (13.5\%), and Alzheimer's disease (9.5\%) (Table II).

Pain was the most common symptom $(74.2 \%$ had pain and $31.7 \%$ had pressure ulcers). Training must be provided for the caregivers on some aspects in order to be more effective in improving the patients' well-being. The leading training topic that the caregivers need was nutrition of the patients $(30.3 \%)$ followed by hygiene $(21.2 \%)$ and general care $(18.2 \%)$ (Table III). 
Table II. The distribution of the diseases of the patients who applied for HCSs

\begin{tabular}{|c|c|c|c|}
\hline & & $\mathbf{n}$ & $\%$ \\
\hline \multirow{8}{*}{$\begin{array}{l}\text { Neurological } \\
\text { diseases }\end{array}$} & $\begin{array}{l}\text { Cerebrovascular } \\
\text { diseases }\end{array}$ & 44 & 13.5 \\
\hline & Alzheimer's disease & 31 & 9.5 \\
\hline & Hemiplegia & 28 & 8.6 \\
\hline & Parkinson's disease & 12 & 3.7 \\
\hline & $\begin{array}{l}\text { Mental retardation/ } \\
\text { cerebral palsy }\end{array}$ & 10 & 3.1 \\
\hline & Dementia & 9 & 2.8 \\
\hline & $\begin{array}{l}\text { Other neurologic } \\
\text { diseases }\end{array}$ & 6 & 2.3 \\
\hline & Epilepsy & 6 & 1.8 \\
\hline \multirow{3}{*}{$\begin{array}{l}\text { Cardiovascular } \\
\text { diseases }\end{array}$} & Hypertension & 63 & 19.3 \\
\hline & Coronary artery disease & 25 & 7.7 \\
\hline & Congestive heart failure & 8 & 2.5 \\
\hline \multirow{3}{*}{ Endocrine diseases } & Diabetes mellitus & 27 & 8.3 \\
\hline & Hypothyroidism & 4 & 1.2 \\
\hline & Obesity & 2 & 0.6 \\
\hline Respiratory diseases & $\begin{array}{l}\text { Chronic obstructive } \\
\text { pulmonary disease }\end{array}$ & 8 & 2.5 \\
\hline \multirow{2}{*}{$\begin{array}{l}\text { Musculoskeletal } \\
\text { disorders }\end{array}$} & Rheumatoid arthritis & 3 & 0.9 \\
\hline & Lumber discopathy & 3 & 0.9 \\
\hline \multirow{3}{*}{ Psychiatric diseases } & Atypical psychosis & 8 & 2.5 \\
\hline & Schizophrenia & 4 & 1.2 \\
\hline & Depression & 2 & 0.6 \\
\hline \multirow{5}{*}{ Cancer } & Breast cancer & 3 & 0.9 \\
\hline & Brain tumor & 3 & 0.9 \\
\hline & $\begin{array}{l}\text { Chronic lymphocytic } \\
\text { leukemia }\end{array}$ & 2 & 0.6 \\
\hline & Parotid tumor & 1 & 0.3 \\
\hline & Lung cancer & 1 & 0.3 \\
\hline \multirow{2}{*}{$\begin{array}{l}\text { Nephro-urologic } \\
\text { diseases }\end{array}$} & $\begin{array}{l}\text { Benign prostatic } \\
\text { hyperplasia }\end{array}$ & 4 & 1.2 \\
\hline & Chronic renal failure & 2 & 0.6 \\
\hline Accidents & $\begin{array}{l}\text { Workplace and traffic } \\
\text { accidents }\end{array}$ & 3 & 0.9 \\
\hline Others* & & 3 & 0.9 \\
\hline Total & & 326 & 100.0 \\
\hline
\end{tabular}

* Others including filariazis, spondilodiscitis.
Table III. Training needs mentioned by family members for the care of the patients

\begin{tabular}{lcc}
\hline & $\mathbf{n}$ & $\mathbf{\%}$ \\
\hline Nutrition of the patients & 20 & 30.3 \\
Hygiene of the patients & 14 & 21.2 \\
General care of the patients & 12 & 18.2 \\
Wound care of the patients & 10 & 15.2 \\
Exercise for the patients & 7 & 10.6 \\
Oral care of the patients & 2 & 3.0 \\
Positioning of the patients & 1 & 1.5 \\
Total & $\mathbf{6 6}$ & $\mathbf{1 0 0 . 0}$ \\
\hline
\end{tabular}

As HCSs, 41 patients received medical dressing, while 13 were trained on exercise by a physiotherapist, 12 were hospitalized. Percutaneous endoscopic gastrostomy replacement was performed in 8 patients, while urinary and nasogastric catheters were changed in 10 patients.

\section{Discussion}

Prolongation of life expectancy of people leads to an increase in chronic diseases and morbidity problems of the people so that a huge demand for care and caregivers appear. In France elderly population percentage has increased just two folds in the past 100 years; however, Japanese society is aging at an unprecedented rate [17]. In addition, the very elderly (aged 75 years and over), comprising more frail people constituting more than $10 \%$ of the population in 2008 in Japan [16]. And many of these Japanese elderly hope to spend their later years not only healthy but also to achieve great accomplishments in their lives [18]. In the future, health care of the geriatric patients will show important maintainability issues in terms of economy, manpower and health systems all over the world including Turkey [19]. It seems that Turkey needs to develop home care and services other than health in order to have an end-of-life in dignity.

In our study, mean age of the patients was 72.6 years and $61.7 \%$ were women and the percentage of women was higher than the other studies and also their mean age was higher than the others, except for one, the study of Catak and et al $[20,21]$. Although aging rate in Turkey is not as fast as in Japan, it is obvious that it is increasing for women enforcing living alone with all its handicaps. Social security inclusion levels ranged from 52.8 to $94.0 \%$ in various studies, and the level was found as $79.2 \%$ in this study [2023]. Social security makes aging people feel more confident 
about future, however, if one does not have it that means more complicated health problems cannot be solved timely. If that is the issue, then more out of pocket expenditures will lead more poverty with ill health they have.

Catak and et al. reported in their study that the individuals applied for HCSs had hypertension and cerebrovascular diseases at the top of the chronic diseases list while Tuna and et al. reported neurological illnesses as leading diseases $[22,24]$. In our country, the most commonly seen chronic diseases in home care patients are reported as hypertension and cerebrovascular diseases [24], Alzheimer's disease [25] and neurological diseases [26]. In this study, they have not changed so far (hypertension 19.3\% and cerebrovascular diseases 13.5\%) [20]. And neurologic diseases were on the front burner as we classify the diseases according to systems; and within this group cerebrovascular diseases were the leading one. When evaluating on the basis of diseases, hypertension was on the top of the list. It is an important issue to be aware of the relationship between hypertension and cerebrovascular accidents for preventive measures. Primary care physicians (PCPs) have to follow up their hypertensive patients more closely for prevention of its complications like cerebrovascular accidents effecting not only their physical capacity, daily living activities and quality of their lives but also dependency on anyone who would care them [26, 27]. High prevalence of chronic diseases and related disabilities occurring in time also physically limits the elderly leading to a great need of rehabilitation. Comprehensive and modern rehabilitation services have to realize and potentiate the elderly individuals' available capacities by working with qualified professionals in multidisciplinary and interdisciplinary approaches. The target of this rehabilitation is to ensure the highest possible level of independence and as far as possible to gain and conserve the ability to perform their activities of daily living. Especially, among elderly individuals who are over 85 years old, $40 \%$ is in need of support for daily living activities [28]. Nutrition is also another daily problem for their follow-up programs [29].

With the progress of the hospice movement and aging of the US population, patterns of diagnosis among patients within hospice care have been evolved. There was a shift of diseases from cancer to chronic debilitating diseases, and $64.4 \%$ of patients died in hospices due to their chronic diseases such as frailty, atherosclerotic, and respiratory diseases [1]. It seems that the profile of people in need of HCSs and using them right now is similar as we do not have any information for comparison with the past. It is obvious that high prevalence of chronic diseases and related disabilities occurring in time lead to a great need of rehabilitation of elderly that have to have multidisciplinary and interdisciplinary approaches. However, it is hard to achieve this with not only limited economic but also limited human resources for comprehensive and modern rehabilitation services to potentiate the available capacities and conserve the ability to perform their activities of daily living of the elderly [28]. PCPs have the responsibility of the management and organization of these activities and services both due to its principles comprehensive-holistic approach and current legal arrangements [13,30].

In our country, home care of elderly is given by family members, especially by women. Home caregivers were women $(78-89 \%)$ and $56 \%(34-54 \%)$ was spouse $[25,31]$. Most of the individuals were reported as over 65 years old and caregivers were from a family member in most of the studies performed on home care in Turkey [21]. Caregivers in this study are also family members and most of the time they were wives and children similar to another study [22]. It is obvious that any home care program has to cover the needs of caregivers, especially women for a better and successful management of the elderly needs.

Aksayan and Cimete's study, in 1998, defined that $63.1 \%$ elderly has chosen home care, $86.5 \%$ has chosen the care given at home in order to live with family members [32]. When elderly individuals chose to have care at their own house, it becomes much harder for family members to be caregiver of their elderly [33]. The reasons for that difficulty can be listed as increase in health problems of elderly as life expectancy is increased, financial problems leading to internal and external migration which also causes transformation of extended families to nuclear ones living in smaller houses and participation of more women in working life, perspective of youth to elderly and intergenerational communication problems [28, 34].

A significant portion of the demand of the caregivers other than health care was their report needs like diaper usage, medication report, and medical board report for handicapped. In addition to health problems, economic burden and logistic problems growing each year lead the caregivers applying for HCSs for the reports given by the government. These reports let them have a kind of indirect financial support. By this way, economic responsibilities of the individuals and/or their caregivers could be shared by the government. So the reports needed throughout the care of the elderly should be accepted as a part of home care services. These official visits can be organized without any more application after the first medical visit and can be 
organized as a part of social services supported by social workers. When needed these visits can also be accompanied by health workers for medical needs including physical or laboratory examinations, evaluation of their physical, psychological conditions, or nutritional status. However, all these needs could be done with an appropriate time planning by PCPs [35].

Among HCSs some were highlighted and mentioned more noteworthy. These services begin with physical examination and medical therapy in this study, as mentioned in the study of Watanabe et al [36]. The following HCSs needed were injections and urinary catheterizations and wound care, medical dressings similar to studies reported as the most common reason for HCSs applications [20, 28].

In the case of formal or informal, all caregivers including family members should be trained about caring the bedridden or handicapped patients at home so that early diagnosis of various conditions and prevention of complications can be achieved resulting with higher quality of life of the patients. In our study, training needs of caregivers were especially focused on nutrition, hygiene and general care of the patients. Appropriate educational interventions on these topics cannot only prevent possible complications but also delay or even prevent the families' burnout throughout their care giving period due to their emotional burden.

The study has shown some of the aspects of HCSs so that issues including medical, nursing, social and welfare problems can be visible for all parties that need to be involved. People who benefit from HCSs were mostly women, elders, chronically ill patients with decreased functional status and bedridden, and most of them were in low socio-economic status. Their caregivers could also need social support not only in economic means but also trainings for better care they can offer for their mothers, fathers or spouses.

HCSs are interdisciplinary team care that provide comprehensive care addressing all aspects of the problems and all these begin with patients, caregivers and PCPs. PCPs have to monitor homecare patients appropriately from the beginning and manage referrals when needed and support the family members in training on general care, sanitation, and nutrition of their patients. However, HCSs have to include many partners in addition to PCPs' and health workers in hospitals because the needs are so complex and closely associated with economy, industry and culture. Therefore, there is a need of a wide integration and cooperation of community with related administrative units, industries, medical and educational institutions using an interdisciplinary approach.

\section{References}

1. Meier D E, McCormick E, Lagman R L. Hospice: Philosophy of care and appropriate utilization in the United States. 2016 May 05, 2016 [cited 201605 May ]; Accessed on 2016 May 05 http://www.uptodate.com/contents/hospicephilosophy-of-care-and-appropriate-utilization-in-theunited-states? source=searc.

2. National Hospice and Palliative Care Organization. History of Hospice Care. 3/28/2016. Accessed on 2016 March 28 : http://www.nhpco.org/i4a/pages/index.cfm?pageid=3285.

3. Choi J Y. Does process quality of inpatient care matter in potentially preventable readmission rates? 2012. Dissertation. University of Minnesota Digital Conservancy, Accessed on 2016 May 05 http://hdl.handle.net/11299/167033

4. Chiang JK, Kao YH. The impact of hospice care on survival and cost saving among patients with liver cancer: a national longitudinal population-based study in Taiwan. Support Care Cancer 2015;23:1049-55 Accessed on 2016 May 05 doi: 10.1007/s00520-014-2447-1.

5. Bentur N. Hospital at home: what is its place in the health system? Health Policy 2001;55: 71-9.

6. Çoban M, Esatoğlu A E. Evde bakım hizmetleri konusunda görüş belirleme: Sosyal Sigortalar Kurumu Ankara Eğitim Hastanesi doktorları ve hemşireleri üzerinde bir uygulama. Ankara: 9.Ulusal Halk Sağlığı Kongresi Bildiriler Kitabı, 2004;2-6 Kasım:266 (Poster Bildiri)

7. Belloir M, Riou F. [Nursing staff's knowledge and attitudes concerning preventive oral hygiene in palliative care]. Recherche en Soins Infirmiers 2014;117:75-84. doi: 10.3917/ rsi.117.0075

8. Dunkley S, Sales R. The challenges of providing palliative care for people with intellectual disabilities: a literature review. Int J Palliat Nurs 2014;20:279-84. doi: 10.12968/ ijpn.2014.20.6.279.

9. Yılmaz M, Sametoğlu F, Akmeşe G, et al. Sağlik hizmetinin alternatif bir sunum şekli olarak evde hasta bakımı. Istanbul Med J 2010;11:125-32.

10. Danış M Z. Toplum temelli bakım anlayışı. Ankara: T.C. Başbakanlık Özürlüler İdaresi Yayını Öz-veri Dergisi 2005a;21 445-59.

11. Özer Ö, Şantaş F. Kamunun sunduğu evde bakım hizmetleri ve finansman1. ACU Sağlik Bil Derg 2012;3:96-103.

12. Alnıgeniş E. Evde bakım hizmetlerine bakış. Sağlık Düşüncesi ve Tip Kültürü Dergisi 2009.Accessed on 2016 March 05 http://sdplatform.com/Dergi/240/Evde-bakimhizmetlerine-bakis.aspx

13. Resmi Gazete. E.B.H.S.H.Y.R., 3895 sayılı "Sağlık Bakanlığınca Sunulan Evde Sağlık Hizmetlerinin Usul ve Esasları Hakkında Yönerge”. 10.3.2005-25751 01.02.2010

14. TÜİK, Nüfus Projeksiyonları 2013-2075. Türkiye İstatistik Kurumu Haber Bülteni, 2013. Accessed on 2016 March 05 http://www.tuik.gov.tr/PreHaberBultenleri.do?id=15844

15. Subaşı N, Öztek Z. Türkiye' de karşılanmayan bir gereksinim: Evde bakım hizmeti. TSK Koruyucu Hekimlik Bülteni 2006;5:19-31. Accessed on 2016 March 05 http://www. scopemed.org/ 
16. Arai H, Ouchi Y, Yokode M, et al. Toward the realization of a better aged society: messages from gerontology and geriatrics. Geriatr Gerontol Int 2012;12:16-22. doi: 10.1111/j.14470594.2011.00776.x.

17. Bloom D E, Canning D, Sevilla J. The demographic dividend: A new perspective on the economic consequences of population change. Santa Monica, CA: Rand Corporation, 2003. Accessed on 2016 March 05 http;//www.rand.org/ content/dam/rand/pubs/monograph_reports/2007/MR1274. PDF

18. Önder T, Anuk T, Kahramanca Ş, Yıldırım AC. Evde bakım hizmetinden yararlanan hastaların sosyodemografik özellikleri ve tıbbi durumlarının değerlendirilmesi. Dicle Tıp Derg 2015;42:342-5.doi: 10.5798/diclemedj.0921.2015.03.0586

19. Carmichael F, Charles S, Hulme C. Who will care? Employment participation and willingness to supply informal care. J Health Econ 2010;29:182-90.Accessed on 2016 March 16 htttp:/www.sciencedirect.com/science/article/pii/ SO167-6296(09)00120-9

20. Limnili G. Özçakar N. The characteristics of applications to home health care service and expectations. Turkish J Fam Pract 2013;17:13-7. doi:10.2399/tahd.13.81994

21. Akdemir N, Bostanoğlu H, Yurtsever Y, Kutlutürkan S, Kapucu S, Canlı Özer Z. Needs of home care services for the bedridden patient's problems living in their home. Dicle Med J 2011; 38: 57-65.

22. Tuna RY, Özdemir Ü, Güden E, Demirel İ, Öksüzkaya A. Evde Sağlik Hizmetleri Kayseri Örneği. 15. Ulusal Halk Sağlığı Kongresi 2012. Accessed on March 05, 2016. http://halksagligiokulu.org/anasayfa/ compenents/com_booklibrary/ebooks/15.UHSK $\% 20$ K\%C4BOTAP_14_10_12.PDF

23. Bobinac A, van Exel NJ, Rutten FF, Brouwer WB. Caring for and caring about: disentangling the caregiver effect and the family effect. J Health Econ 2010;29:549-56. doi: 10.1016/j. jhealeco.2010.05.003

24. Çatak B, Kılınç AS, Badıllığlu O, Sütlü S, Erkan Sofuğolu A, Aslan D. Burdur'da evde saglik hizmeti alan yasli hastalarin profili ve evde verilen saglik hizmetleri. Turkish Journal of Public Health 2012;10:11-20.

25. Altun İ. Hasta yakınlarının bakım verme rolünde zorlanma durumları. I. Ulusal Evde Bakım Kongre Kitab1 1998:24-26.
26. TzourioC, Laurent $S$, DebetteS. Ishypertensionassociated with an accelerated aging of the brain? Hypertension 2014;63:894903. doi: 10.1161/HYPERTENSIONAHA.113.00147

27. Kovács T. [The effect of angiotensin receptor blockers in cerebrovascular disorders and dementia: bonus in addition to the antihypertensive effect]. Ideggyogy Sz 2014; 67:149-68.

28. Fadıloğlu Ç, Tokem Y. Geriatrik rehabilitasyonda hemşirenin rolü. Türk Geriatri Dergisi 2004; 7: 241-6.

29. Atasoy B M, Özgen Z, Yüksek Kantaş Ö, et al., Interdisciplinary collaboration in management of nutrition during chemoradiotherapy in cancer patients: a pilot study. Marmara Med J 2012;25:32-6 doi: 10.5472/ MMJ.2011.02072.1.

30. Çifçili S (ed).Aile Hekimleri için Yaşlı Sağlığında Bütüncül Yaklaşım. Cöbek Ünalan P, Serap Çifçili S, Apaydın Kaya Ç, et al. 1. Bask1. İstanbul: Deomed Yayınc1lık, 2011:340.

31. Dramalı A, Demir F, Yavuz M. Evde Kronik Hastaya Bakım Veren Hasta Yakınlarının Karşılaştıkları Sorunlar. I. Ulusal Evde Bakım Kongresi Kitab1, İstanbul, 1998. 1998.httğ:// www.worldcat.org/title/i-ulusal-evde-bakım-kongresi-kitab24-26-eylul-1998-istanbul/oclc/85770000

32. Aksayan S, Cimete C. Kronik Hastalıklı Bireylerin Evde Bakım Gereksinimleri Olanakları ve Tercihleri. I. Ulusal Evde Bakım Kongresi Kitab1, İstanbul, 1998.

33. Karahan A, Güven S. Yaşl11ıkta evde bakım. Turkish Journal of Geriatrics 2002;5: 155-9.

34. Coşkun M. Samsun İl Merkezinde Yaşayan Yaşliların Sürekli Kayg1 Düzeyleri ve Bazı Sosyoekonomik Etmenleri. Yayımlanmamış Uzmanlık Tezi, Samsun, Ondokuz Mayıs Üniversitesi, 1998.Accessed on 2016 March 05 http:// docplayer.biz.tr/6635903-Huzurevinde-yaslilarin-anksiyeteve-depresyon-duzeylerinin-belirlenmesi.html

35. Özgür F, Gültekin E, Nazlı İ, Çelik İ, Ede G. Evde sağlı/ bakım hizmetleri konusunda aile hekimleri ve aile sağlığ elemanlarının beklenti, gereksinimi ve sorunları. Marmara Med J 2012;25:.21. http://mmj.dergisi.org/pdf/pdf_MMJ654.pdf (sözlü sunum)

36. Watanabe G, Nakayama S, Yamagiwa T, Ito S, Fukuda A, Yamaoka Y. [The role of cooperating hospitals in homecare]. Gan to Kagaku Ryoho. Cancer \& Chemotherapy 2013;40 Suppl 2: 191-4. 